\title{
Municipal Engineer: Referees 2015
}

The following is a list of referees who have reviewed papers for Municipal Engineer between 1 December 2014 and 30 November 2015. The Institution of Civil Engineers is very grateful for their assistance.

We are continually looking for suitable reviewers for papers submitted to Municipal Engineer. Papers published in the Proceedings of the ICE must be submitted to at least two independent referees to judge accuracy, style, impact, importance and interest.

If you are interested in reviewing articles on any topic related to engineering history and heritage, please submit your name, qualifications
R. Andrew
E. Antonio
C. Atkinson-Palombo
K. Balaji Rao
S. Balouch
J. Bateman
D. Blackwood
M. Bordagaray
H.S. Chang
B. Clarke
D. Collings
J. Coutinho-Rodrigues
O. Demir
A. Faggi
J. Foster-Clark
A. Geymen
A. Gibbs
J. Guiver
S. Hengirmen Tercan
A. Horr
I. Jenkinson
H. Khabbaz
D. Komakech
S. Leminen
B. Li

or $\mathrm{CV}$, and areas of expertise. We are in need of individuals who will agree to review papers in a timely fashion (within 3 to 4 weeks of receipt) and provide confidential feedback to the Editorial Advisory Panel concerning the quality of the paper and any suggested revisions that would be appropriate.

If you are such a person, please contact Claire Robinson (tel.: +44 (0)207 665 2241; e-mail: claire.robinson@icepublishing.uk) for more information on the referee process.
R. Marques
D. Mehta
S. Miguel
O. Moraes
S. Nelson
R. Normann
E. Osaji
J. Parry
S. Rafeeqi
T. Russell
B. Sager
M. Salheen
A. Savage

M.S. Shaheed

P. Sheppard

M. Smith

A. Stainsby

J. Thomson

M. Thorn

P. Uamturapojn

M. Vieri

Q. Wu

Y. Yuan 